\title{
HISTOCHEMICAL LOCALIZATION OF ENZYMES AND LIPIDS IN THE OVARY OF A VESPERTILIONID BAT, Scotophilus heathi, DURING THE REPRODUCTIVE CYCLE
}

\author{
SINGH, U. P., ${ }^{1}$ KRISHNA, A., ${ }^{1}$ SMITH, T. D. ${ }^{2}$ and BHATNAGAR, K. P. ${ }^{3}$ \\ ${ }^{1}$ Department of Zoology, Banaras Hindu University, Varanasi, India \\ ${ }^{2}$ School of Physical Therapy, Slippery Rock University, Slippery Rock, PA 16057, USA \\ ${ }^{3}$ Department of Anatomical Sciences and Neurobiology, School of Medicine, University of \\ Louisville, Louisville, KY 40292, USA \\ Correspondence to: Kunwar Bhatnagar, Department of Anatomical Sciences and Neurobiology, School of \\ Medicine, University of Lousiville, Louisville, KY 40292, USA, e-mail: bhatnagar@ louisville.edu \\ Received July 3, 2003 - Accepted September 9, 2003 - Distributed February 28, 2005
}

(With 13 figures)

\begin{abstract}
The present study describes seasonal changes in $\Delta^{5} 3 \beta$ hydroxysteroid dehydrogenase (3 $\beta$-HSD), glusose-6 phosphates dehydrogenase (G-6-PD), and lipids in the ovary of a vespertilionid bat, Scotophilus heathi. Total lipids and $3 \beta$-HSD activity are restricted to thecal and interstitial cells of the ovary. The total lipids, $3 \beta-\mathrm{HSD}$, and G-6-PD significantly increase during recrudescence, and remain high during winter dormancy and breeding as compared to the other reproductive phases. High incidence of lipids and enzyme activity in interstitial cells during the breeding period and at the time of ovulation clearly suggests that these cells are actively involved in steroidogenesis. A decline in enzymes and lipid activity during winter dormancy, which correlates with the declining levels of steroidogenesis, might be the factors responsible for prolonged survival of the Graafian follicle in the ovary of S. heathi.
\end{abstract}

Key words: enzymes, lipids, ovary, reproductive cycle, Scotophilus heathi.

\section{RESUMO}

O presente estudo descreve as mudanças sazonais na $\Delta^{5} 3 \beta$ hidroxiesteróide desidrogenase (3 $\beta$-HSD), glicose-6 fosfato desidrogenase (G-6-PD), e lipídios no ovário de um morcego vespertilionidae, Scotophilus heathi. As atividades totais dos lipídios e do $3 \beta$-HSD estão restritas às células tecais e intersticiais do ovário. Os lipídios, 3 $\beta$-HSD e G-6-PD totais, aumentaram significantemente durante a recrudescência, e permaneceram elevados durante a dormência de inverno e o período de acasalamento, quando comparados a outras fases reprodutivas. A alta incidência de atividade de lipídios e enzimas nas células intersticiais durante o período de acasalamento e durante o período de ovulação sugere claramente que estas células estão ativamente envolvidas na esteroidogênese. O declínio da atividade dos lipídios e enzimas durante a dormência de inverno, o qual se correlaciona com os níveis decrescentes da esteroidogênese, podem ser o fator responsável pela longa sobrevivência do folículo de De Graaf no ovário do S. heathi.

Palavras-chave: enzimas, lipídios, ovário, ciclo reprodutivo, Scotophilus heathi.

\section{INTRODUCTION}

The discovery of certain unique reproductive specializations such as prolonged survival of the Graafian follicle and sperm storage in the female genital tract have given great impetus to the study of chiropteran reproduction. While several authors have reviewed the progress of research on reproduction from time to time, detailed studies on ovarian cycle and steriodogenesis are very few (Oxberry, 1979; Racey, 1982; Heideman, 1989; Singh \& Krishna, 1997; Martin \& Bernard, 2000). The cellular location and relative activities of total phospholipids and neutral lipids, substrates for sex 
steroids and steroidogenesis, enzymes $3 \beta-\mathrm{HSD}$, and glucose-6-phosphates (G-6-PD) are described in the ovary of bats Tadarida (Jerrett, 1979); Taphozous (Jaroli \& Lall, 1987); Rinolaphus eurale (Tsvetkov \& Takeva, 1988); and Macrotus (Crichton et al., 1990). No such information is available on any tropical bat, particularly in relation to the unique reproductive features, which are prolonged survival of the Graafian follicle and delayed ovulation.

Scotophilus heathi (Order: Chiroptera; Family: Vespertilionidae) is seasonally monoestrous in Varanasi, India, and presents the phenomenon of prolonged survival of the Graafian follicle, where the large antral follicles formed during November survive until ovulation in March (Krishna \& Singh, 1992). Previous studies in our laboratory on the ovary of S. heathi have demonstrated several unique morphological and physiological characteristics (Singh \& Krishna, 1996; Abhilasha \& Krishna, 1996; Doval \& Krishna, 1998; Krishna \& Abhilasha, 2000). The ovary of S. heathi, which has been shown to produce high concentrations of androstenedione, exhibits features such as the extensive presence of hypertrophied thecalinterstitial cells (TICs), prolonged retention of large antral follicles, absence of antrum in large antral follicles, hypertrophied granulosa cells, and accumulation of glycogen in granulosa cells, etc. (Singh \& Krishna, 1996; Abhilasha \& Krishna, 1996; Doval \& Krishna, 1998; Krishna \& Abhilasha, 2000). It has been reported that interstitial cells in some bat species are better equipped for steroidogenic function than mature follicles (Jerret, 1979). Jaroli \& Lall (1987) reported high enzyme reaction in the degenerative follicles. Thus, follicular atresia seems to provide support for steroidogenic activity. Therefore, the present study was undertaken on S. heathi to elucidate the distribution and seasonal variation of lipids and steroidogenic enzymes in the ovary during the various reproductive phases and to determine whether these changes in lipids and enzymes in the ovary are responsible for prolonged survival of the Graafian follicle in the ovary of S. heathi.

\section{MATERIALS AND METHODS}

All experiments were conducted in accordance with the principles and procedures approved by the departmental research committee at Banaras Hindu University, Varanasi, India. Six bats were trapped alive every month on the University campus and at an adjacent area near Varanasi $\left(25^{\circ} \mathrm{N}, 83^{\circ} \mathrm{E}\right)$. Because no significant difference was found between body weight, ovarian weight, and reproductive condition in individual groups over the two-year study of the reproductive cycle, the data of both years were pooled. Bats weighing less than $20 \mathrm{gms}$, with wing span of less then $40 \mathrm{~cm}$, undeveloped gular gland, and darker pelage were considered immature and excluded from this study. Body and ovarian masses of the adult bats were recorded within two hours of capture.

The climate in Varanasi is subtropical and the cold season lasts from November to February, with extremely cold conditions from mid-December to January (mean low $4 \pm 2^{\circ} \mathrm{C}$ and mean high $16 \pm 4^{\circ} \mathrm{C}$ ) and short day-length (10L: 14D). The insect population is lower than during the other months of the year. With their body mass already increased due to fat accumulation, bats enter into winter dormancy during this period (similarly to what happens before hibernation in temperate-zone bats). Because of not foraging, during this period bats exhibit hypothermia with an anal temperature lower than other periods of the year.

The reproductive cycle of S. heathi is divided in the following five phases: (1) quiescence (AugustSeptember): only primordial and primary follicles are present in the ovary; (2) recrudescence (November): the recruitment of ovarian follicles, with few antral follicles appearing in the ovary; (3) winter dormancy (mid-December to mid-January): females remain torpid and ovarian activity is retarded; (4) breeding (February): reproductive activity is characterized by a second wave of follicular growth and many antral follicles; (5) pregnancy (March to July): pregnant females are characterized by the formation of a single corpus luteum.

\section{Histochemical detection of enzymes}

Six ovaries from each reproductive phase were dissected, weighed, immediately frozen, and sectioned on cryostat $\left(-20^{\circ} \mathrm{C}\right)$ at $10 \mu \mathrm{m}$ thickness. Twenty sections from each ovary were studied for each reaction. The incubation medium for $3 \beta$-HSD consisted of nitroblue tetrazolium. Nicotinamide adenine dinucleotide $\left(\mathrm{NAD}^{+}\right)$and pregnenolone dissolved in 2-2 dimethylformamide were used as substrates. The methods of Baillie et al. (1966) were employed to 
demonstrate $\Delta^{5} 3 \beta$ hydroxysteroid dehydrogenase and glucose-6 phosphates dehydrogenase (G-6-PD) activity. The reaction medium for G-6-PD consisted of phosphate buffered ( $\mathrm{pH}$ 7.4) glucose-6- phosphate, nicotinamide adenine dinucleotide phosphate (NADP), and nitroblue tetrazolium. Control incubation was performed without the substrate. Histochemical reaction was observed and reaction intensity was graded visually on an arbitrary scale (from none $=-$ $;+=$ light $;++=$ moderate $;+++=$ high to $++++=$ intense). All observations were made by a single investigator to avoid intraobserver differences.

\section{Histochemical detection of lipids}

The other six ovaries from each reproductive phase were fixed in formol calcium and $10 \%$ neutral buffered formalin for the histochemical detection of the lipids. Twenty cryostat sections $(10 \mu \mathrm{m})$ thick were washed briefly in water and stained with Sudan black B (for general lipids) or Nile blue (for neutral lipids and phospholipids) for each group.

\section{Statistical analysis}

Data are presented as means \pm SEM. Body mass and ovarian mass were initially analyzed by one-way ANOVA with repeated measures over time, followed by the Neuman-Keuls test for multiple comparisons. Differences were considered significant at $\mathrm{p}<0.05$.

\section{RESULTS}

Changes in enzymes and lipids

The cellular location and relative activity of total phospho and neutral lipids, and enzymes $3 \beta$ HSD and G-6-PD are shown in Tables 1 and 2. The results clearly demonstrate that interstitial cells were the major sites of lipid deposition.

TABLE 1

Histochemical distribution of enzymes and lipids in the ovary of S. heathi.

\begin{tabular}{|l|c|c|c|c|c|c|}
\hline \multirow{2}{*}{ Chemical substance } & \multicolumn{2}{|c|}{ Healthy follicle } & \multicolumn{2}{|c|}{ Atretic follicle } & \multirow{2}{*}{ IC } & \multirow{2}{*}{ ST } \\
\cline { 2 - 6 } & GC & TC & GC & TC & & - \\
\hline$\Delta^{5} 3 \beta$ HSD & - & +++ & +++ & + & ++++ & - \\
\hline G-6-PD & - & + & - & + & +++ & + \\
\hline $\begin{array}{l}\text { Diffuse lipo-protein } \\
\text { (Sudan black B) }\end{array}$ & ++ & ++ & ++ & ++ & +++ & + \\
\hline $\begin{array}{l}\text { Neutral lipids (Staining } \\
\text { pink with nile blue) }\end{array}$ & - & - & + & ++ & ++ & + \\
\hline $\begin{array}{l}\text { Phospholipids (Staining } \\
\text { blue with Nile blue) }\end{array}$ & ++ & +++ & ++ & +++ & ++ & + \\
\hline
\end{tabular}

GC = granulosa cells; TC = thecal cells; IC = interstitial cells; ST = stroma. Intensity of histochemical reaction as visually determined; none $=-$; light $=+$; moderate $=++$; high $=+++$; intense $=++++$.

TABLE 2

Seasonal variation in enzyme and lipid content during various reproductive phases in the ovary of $S$. heathi.

\begin{tabular}{|l|c|c|c|c|c|}
\hline \multicolumn{1}{|c|}{ Chemical substance } & Quies. & Recrud. & Win. Dorman. & Breeding & Pregnancy \\
\hline$\Delta^{5} 3 \beta$ HSD & - & ++ & ++ & ++++ & ++ \\
\hline G-6-PD & - & ++ & ++ & ++++ & + \\
\hline $\begin{array}{l}\text { Diffuse lipo-protein } \\
\text { (Sudan black B) }\end{array}$ & ++ & +++ & +++ & + & + \\
\hline $\begin{array}{l}\text { Neutral lipids (Staining } \\
\text { pink with nile blue) }\end{array}$ & - & - & ++ & + \\
\hline $\begin{array}{l}\text { Phospholipids (Stai ning } \\
\text { blue with Nile blue) }\end{array}$ & ++ & ++ & + & + & + \\
\hline
\end{tabular}

Quies. = quiescence; Recrud. $=$ recrudescence; Win. Dorman. = winter domancy. Intensity of histochemical reaction as visually determined; none $=-$; light $=+$; moderate $=++$; high $=+++$; intense $=++++$. 
Interstitial cells stained intensely black with Nile blue and Sudan black B. Theca and granulosa cells of the follicle also showed a mild reaction with Nile blue and Sudan black B. Formazon deposits indicating 3 $\beta$-HSD and G-6-PD activity throughout the year were mainly observed in the cytoplasm of both interstitial and thecal cells. Granulosa cells and oocytes showed a negative reaction with Nile blue, Sudan black B, and $3 \beta$ HSD and G-6-PD. During pregnancy luteal cells exhibited intense reaction with Sudan black B, Nile blue, and 3 $\beta$-HSD. The number, size, and amount of osmiophilic materials in the lipid droplets usually showed wide intercellular but limited intracellular variation. Cytochemical features of ovaries during different phases of reproductive cycle are described below.

\section{Quiescence}

The ovary contained only primary follicles from August to September. Ovarian interstitial cells contained several vacuoles, which were empty or devoid of lipids while other vacuoles showed intense reaction with Sudan black B. The interstitial cells located around developing follicles showed weak to moderate $3 \beta$-HSD reactions (Fig. 1). The granulosa cells and oocytes showed no reaction.

\section{Recrudescence}

Follicle recruitment and growth begins during this period, with which the first sign of increase in lipid and enzyme activity coincided. The ovary showed intense reaction with Nile blue (Fig. 2) and Sudan Black B (Fig. 3). Large lipid-droplet accumulation during this phase was more intense with Nile blue (Fig. 4). The Sudan black B showed moderate to intense reaction mainly in the interstitial and thecal cells (Fig. 5), while moderate activity was noticed with G-6-PD (Fig. 6).

\section{Winter dormancy}

Ovarian activity declined during this phase. Soon after formation of the antral follicle, with Nile blue staining intense activity was noticed of lipid droplets in the ovary (Fig. 7). This shows the presence of neutral lipids and phospholipids. Lipid deposition presented no difference from that of the recrudescence phase. Weak to moderate activity was observed with $3 \beta$ - HSD during this period (Fig. 8).
Breeding

Remarkable reduction in lipid presence and amount was noticed during this period. Sudan Black B staining showed the presence of both phospho- and neutral lipids (Fig. 9). More intense reaction was seen with $3 \beta-\mathrm{HSD}$ as compared to that observed in other reproductive phases, and this intense activity was mainly seen in interstitial and thecal cells (Fig. 10).

\section{Pregnancy}

Pregnancy lasted from mid-March to early August. The luteal cells showed mild phospholipid accumulation in early pregnancy (Fig. 11). A light to moderate $3 \beta$-HSD staining was seen in the corpus luteum during late pregnancy (Fig. 12).

Changes in body mass and ovarian mass

The body and ovarian masses and remarkable fat deposition are shown in Fig. 13. Body mass begins to increase in September and attains a peak in November due to fat accumulation. Body mass declines in winter dormancy and shows a peak in July (Fig. 13) at the time of advanced stage of pregnancy. The ovarian mass peaks during November. Body and ovarian masses did not show any significant variation during other months of the year.

\section{DISCUSSION}

The present histochemical study shows heavy lipid droplet accumulation and intense activity of $3 \beta$ HSD and G-6-PD enzymes in the interfollicular interstitial thecal cells in the ovary of S. heathi. This suggests that theca-interstitial cells in the ovary of S. heathi are the major site of steroidogenesis as they contain steroid precursor, a lipid containing cholesterol or its esters, together with steroidogenic enzymes. The present study thus further substantiates the earlier study of Singh \& Krishna (1994) who noted ultrastructural features typically associated with steroid-producing cells, such as large numbers of lipid droplets together with mitochondria and a smooth endoplasmic reticulum in the theca-interstitial cells in the ovary of S. heathi. Such extensively developed and steroidogenically-active theca- interstitial cells in the ovary have been reported in some other species of bats, e.g., Otomops (Kayanja \& Muture, 1975); Rhinolophus (Tsvetkov \& Takeva, 1988); and the wood mouse, 
Apodemus sylvaticus (Brook \& Clarke, 1989). A similar increased mass of theca-interstitial cells in the ovarian stroma was shown to be the main site of excess androgen production in women with polycystic ovarian syndrome (Frank et al., 1996).

The enzyme $3 \beta$-HSD has been localized in the ovary of a variety of mammalian species (Baillie et al., 1966; hamsters, Saidapur \& Greenwald, 1978; humans, Sasano et al., 1990). In the present study we noticed positive reaction in granulosa cells of the atretic follicles during a period of delayed follicular growth. In addition, this enzyme activity was also noticed in thecal cells of the antral follicles and luteal cells. As reported previously in Tadarida sp. (Jerret, 1979), steroid synthesis was confirmed in interstitial and luteal cells; the present study corroborates the same finding in S. heathi. A concept emerging in recent years holds that luteinizing hormone stimulates androgen production by ovarian interstitial cells and is the controlling mechanism for follicle selection, ovulation, and atresia (Erickson et al., 1985). The present finding also supports that the product derived from degenerating follicle steroid may influence the rate of growth and selection of other follicles in the vicinity, as suggested by Peters \& McNatty (1980).
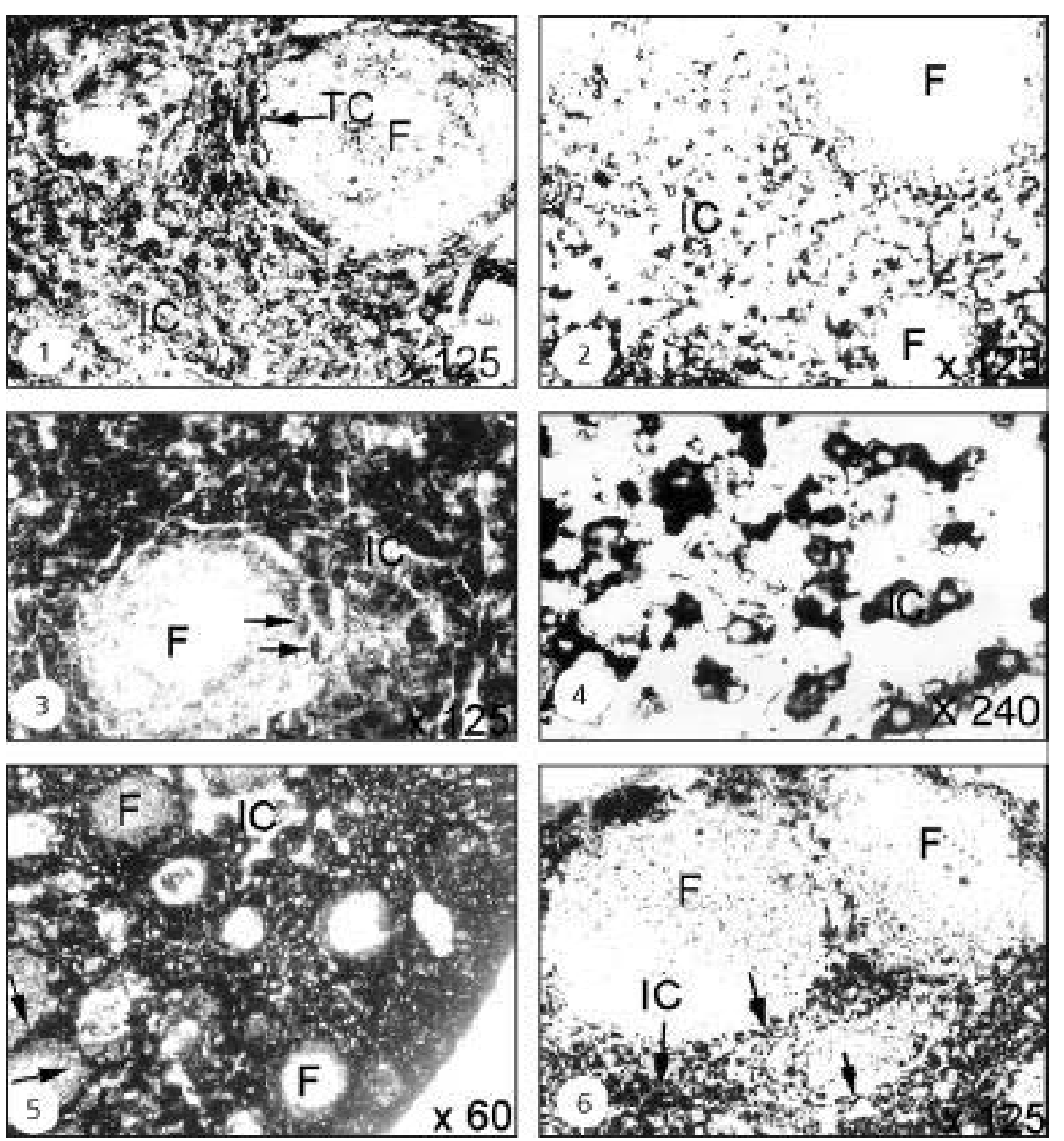

Fig. 1 - Ovary during recrudescence stained with Nile blue to show the accumulation of neutral lipids and phospholipids in the interstitial cells. $x 125$. Fig. 2 - Ovary during quiescence stained with $3 \beta-H S D$ showing weak reaction in interstitial cells and thecal cells. ${ }_{x} 125$. Fig. 3 - Ovary during recrudescence stained with Sudan black B to show the accumulation of lipoprotein in interstitial cells. ${ }_{x} 125$. Arrows indicate positive reaction in thecal cells. Fig. 4 - Ovary during recrudescence stained with Nile blue to show the intense reaction in the interstitial cells. 240 . Arrows indicate positive reaction in thecal cells. Fig. 5 - Ovary during recrudescence stained with sudan black B showing intense reaction in the interstitial cells. $x$ 60. Arrows indicate positive reaction in thecal cells. Fig. 6 - Ovary during recrudescence showing moderate activity of G-6-PD mainly in the interstitial cells. ${ }_{x} 125$. Arrows indicate positive reaction in thecal cells. 

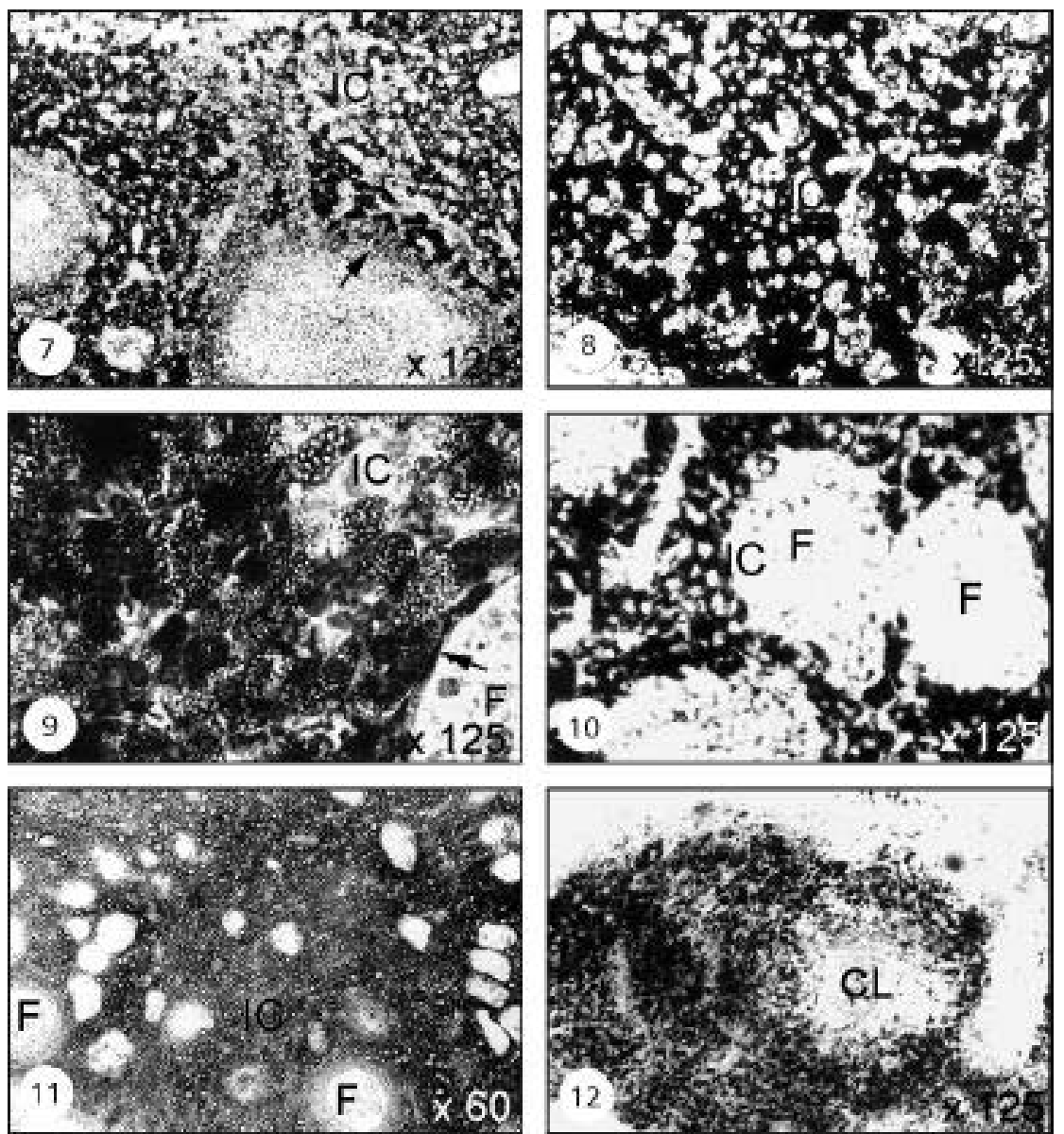

Fig. 7 - Ovary during winter dormancy stained with Nile blue to show the accumulation of neutral and phospholipids in the interstitial cells. $x 125$. Fig. 8 - Ovary during winter dormancy stained with $3 \beta$-HSD showing moderate activity in the interstitial cells. ${ }_{x} 125$. Fig. 9 - Ovary during breeding stained with Sudan black B to show the accumulation of lipoprotein in the interstitial cells. ${ }_{x} 125$. Arrow indicates positive reaction in thecal cells. Fig. 10 - Ovary during breeding showing intense reaction with $3 \beta$-HSD in the interstitial cells. $x 125$. Fig. 11 - Ovary during pregnancy showing intense reaction of phospholipids in the interstitial cells. $x 60$. Fig. 12 - Ovary during pregnancy stained with $3 \beta-$ HSD showing intense reaction in the corpus luteum. 125 .

The atresia peak observed in S. heathi (Krishna \& Singh, 1992) in February is related with intense reaction of these enzymes and may be related with final growth and selection of dominant follicle for ovulation. This has been well supported by an earlier study on bats that was carried out by Jaroli \& Lall (1987). Involvement of intraovarian steroids in the recruitment and selection of dominant follicles has been reported in primates (Hodgen, 1982).

The intensity of the enzymes $3 \beta$-HSD and G6-PD and lipid accumulation in thecal interstitial cells in the ovary of S. heathi showed variations during the reproductive cycle. Peak enzyme activity together with heavy lipid accumulation in thecal interstitial cells during recrudescence coincides with the peak circulating level of steroids shown in S. heathi
(Abhilasha \& Krishna, 1996). Continued presence of high enzyme and lipid concentration during winter dormancy, the breeding phase, and pregnancy suggests active steroidogenesis. The results indicate no evidence of any block in steroidogenesis during the period of delayed ovulation in S. heathi. The results reported here thus confirm the finding of Abhilasha \& Krishna (1996) that delayed ovulation in S. heathi represents a hyperandrogenic condition. Increased lipid accumulation during breeding season could be due to the sharp decline in androstenedione production in S. heathi prior to ovulation.

In the present study we have noticed mild but continued lipid and enzyme presence during the period of delayed ovulation, while ovulation only coincides with features correlating high atresia and 
intense enzyme activity during the breeding phase. This study also supports a similar finding in another bat species, Macrotus (Crichton et al., 1990) in which low enzyme activity in multilaminar follicles in the ovaries was noticed during delayed embryonic development. The present study supports these findings and provides indirect evidence that the low enzyme activity required for follicular survival during the delay period was found in the ovary, but that this activity was not enough for ovulation leading to prolonged survival of the Graafian follicle.

Although autumnal fat deposition is characteristic of hibernating bats (Racey, 1982; Kunz et al., 1998), only a very few tropical bat species exhibit the variation in body weight associated with body fat deposition (Singh \& Krishna, 2002). The present study shows gradual increase in body mass of $\mathrm{S}$. heathi during October and attaining a peak in November. The stored fat is gradually utilized from December to March. It appears that fat stores in S. heathi may be necessary for bat survival during winter when insects are in short supply. Ovarian weight also correlates with body weight in S. heathi.

The present histochemical study has certain limitations in interpreting data because the presence of enzymes and lipid droplets does not directly indicate the steroidogenesis level. In addition, the present study did not yield information on cellular hormone turnover as is the case with immunocytochemical studies. Thus, the persistence of lipids and enzymes in the interstitial cells could only imply that these cells either remain in a static state of storage or in a dynamic state in which synthesis roughly equals or exceeds that occurring during different reproductive phases. Why such extensive thecal interstitial cells develop in the ovary of S. heathi and how such a heavy accumulation of lipids occurs in these cells are intriguing questions.

Furthermore, that the thecal interstitial cells remain active sites of steroidogenesis, despite presence of large antral follicles and corpus luteum in the ovary during breeding phase and pregnancy, constitutes a singular fact. The unique morphological and physiological characteristics of the ovary of S. heathi might be due to the extensive presence of hypertrophied thecal interstitial cells. Both morphological and histochemical studies revealed that interstitial cells in S. heathi are better equipped for steroidogenesis. The lipid and enzyme accumulations and/or release from interstitial cells call for detailed study by direct assay measurement of these enzyme and lipid levels before any prudent conclusion about the steroidogenesis level is drawn.

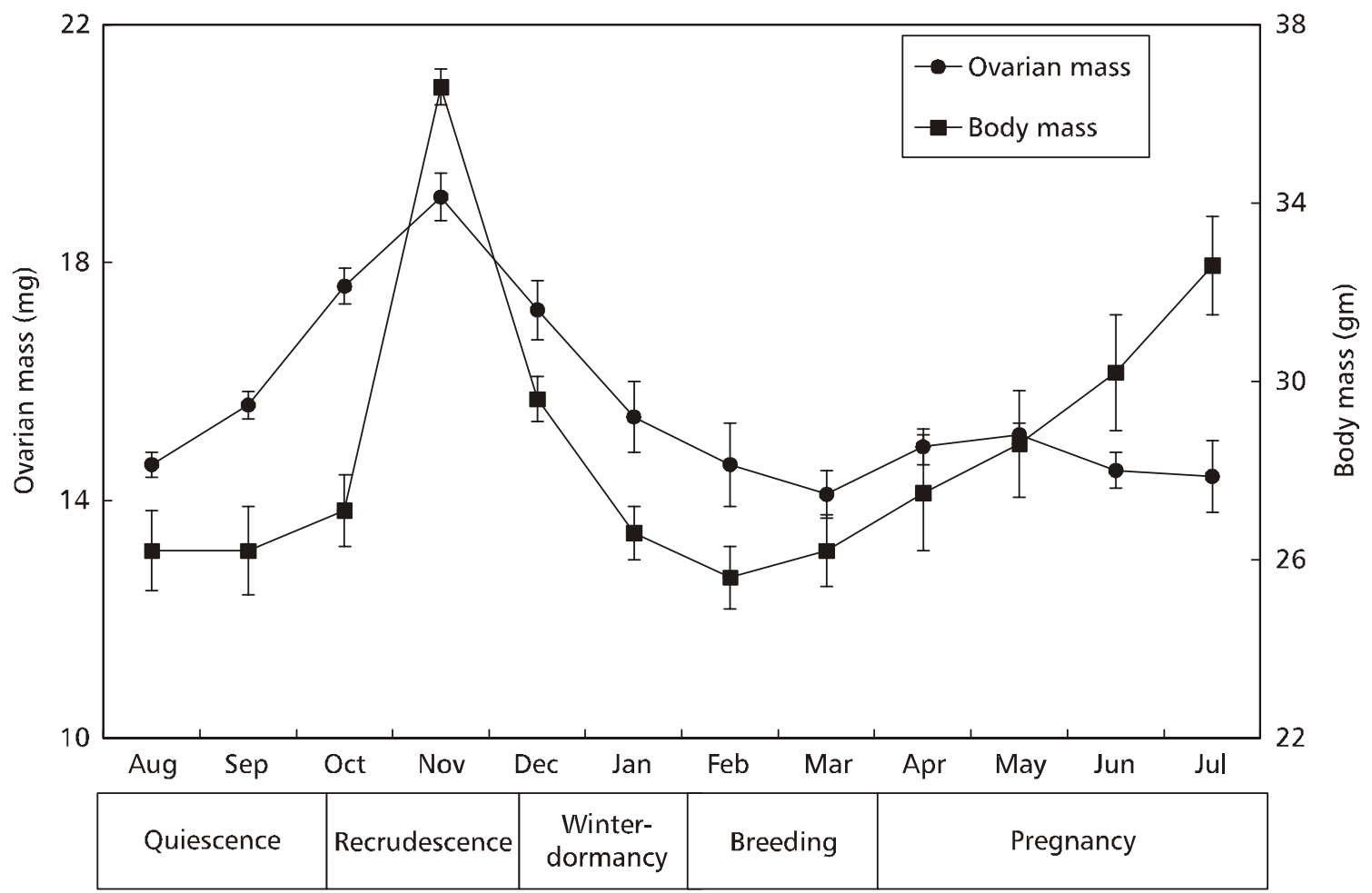

Fig. 13 - Seasonal changes in body and ovarian masses in Scotophilus heathi. 


\section{REFERENCES}

ABHILASHA, A. \& KRISHNA, A., 1996, High androgen production by ovarian thecal interstitial cells: a mechanism for delayed ovulation in a tropical vespertilionid bat., Scotophilus heathi. J. Reprod. Fertil., 106: 207-211.

BAILLIE, A. H., FERGUSON, M. M. \& HART, D. M., 1966, Development of steroid Histochemistry. Academic Press, London, New York.

BROOK, F. A. \& CLARKE, J. R., 1989, Ovarian interstitial tissue of the wood mouse. Apodemus sylvaticus. J. Reprod. Fertil., 85: 251-260.

CRICHTON, E. G., HOYER, P. B. \& KRUTZSCH, P. H., 1990, Cellular composition and steroidogenic capacity of the ovary of Macrotus californicus (Chiroptera: Phyllostomatidae) during and after delayed embryonic development. Cell Tissue Res., 260: 355-366.

DOVAL, J. \& KRISHNA, A., 1998, Ovarian androstenedione production is enhanced by insulin during the period of delayed ovulation in a Indian vespertilionid bat, Scotophilus heathi. J. Reprod. Fertil., 114: 63-68.

ERICKSON, G. F., MAGOFFIN, D. A., DYER, C. A. \& HOFEDITZ, C., 1985, The ovarian androgen producing cells; a review of structure function relationship. Endocr. Rev., 6: 371-399.

FRANK, S., WILLIS, D., MASON, H. \& GILLING-SMITH, C., 1996, Comparative androgen production from theca cells of normal and women with polycystic ovaries. In: R. J. Chang (ed.), Polycystic ovary syndrome. Springer, New York, pp. 154-164.

HEIDEMAN, P. D., 1989, Delayed development in Fischer's pygmy fruit bat, Haplonycteris fischeri, in the Philippines. J. Reprod. Fertil., 85: 363-382.

HODGEN, G. D., 1982, The dominant ovarian follicle. Fertil. Steril., 38: 281-310.

JAROLI, D. P. \& LALL, S. B., 1987, Comparison of histoenzymology alterations in the contralateral ovary of nulliparous and parous females of the bat Taphozous melanopogon melanopogon temmnick (Microchiroptera, Mammalia) displaying absolute dextral dominance of the genital tract. Acta Anat. (Basel), 129: 140-148.

JERRETT, D. P., 1979, Female reproductive patterns in nonhibernating bat. J. Reprod Fertil., 56: 369-378.

KAYANJA, F. I. \& MUTERE, F. A., 1975, The ovary of the insectivorous bat, Otomops martiensseni. Anat. Anz., 137: 166-175.

KRISHNA, A. \& SINGH, U. P., 1992, Morphometric changes in the ovaries of the Indian vespertilionid bat, Scotophilus heathi, with reference to delayed ovulation. Euro. Arch. Biol., 103: 257-264.
KRISHNA, A. \& ABHILASHA, 2000, Mechanism of delayed ovulation in a vespertilionid bat, Scotophilus heathi: role of gonadotrophin, insulin, and insulin like growth factor1. Physiol. Biochem. Zool., 73: 523-529.

KUNZ, T. H., WRAZEN, J. A. \& BURNETT, C. D., 1998, Changes in body mass and fat reserves in prehibernating little brown bats (Myotis lucifugus). Ecoscience, 5: 8-17.

MARTIN, L. \& BERNARD, R. T. F., 2000, Endocrine regulation of reproduction in bats: the role of circulating gonadal hormones. In: E. G. Crichton \& P. H. Krutzsch (ed.), Reproductive biology of bats. CA, Academic Press, San Diego, pp. 27-64.

OXBERRY, B. A., 1979, Female reproductive patterns in hibernating bats. J. Reprod. Fertil., 56: 359-367.

PETERS, H. \& McNATTY, K. P., 1980, The ovary: a correlation of structure and function in mammals. University of California Press, Berkeley, p. 12.

RACEY, P. A., 1982, Ecology of bat reproduction. In: T. H. Kunz (ed.), Ecology of bats. Plenum Press, New York, p. 57-104.

SAIDAPUR, S. K. \& GREENWALD, G. S., 1978, Sites of steroid synthesis in the ovary of the cyclic hamster. A histochemical study. Am. J. Anat., 151: 71-86.

SASANO, H., MORI, T., SASONO, N., NAGURA, H. \& MASON, J. I., 1990, Immunolocalization of $3 \beta$ hydroxysteroid dehydrogenase in human ovary. J. Reprod. Fertil., 89: 743-751.

SINGH, U. P. \& KRISHNA, A., 1994, Seasonal changes in the cytochemical and ultrastructural features of the ovarian interstitial tissue in a vespertilionid bat, Scotophilus heathi. J. Reprod. Biol. Endocrinol., 6: 33-46.

SINGH, U. P. \& KRISHNA, A., 1996, Glycogen accumulation in the ovarian follicle of Indian vespertilionid bat, Scotophilus heathi during the period of delayed ovulation. Zool. Sci., 13: 893-897.

SINGH, U. P. \& KRISHNA, A., 1997, A mini review on the female chiropteran reproduction. J. Endocrinol. Reprod., 1: $1-19$.

SINGH, U. P. \& KRISHNA, A., 2002, Seasonal changes in circulating steroid concentration and their correlation with the ovarian activity in the female sheath-tailed bat, T. longimanus. J. Exp. Zool., 292: 384-392.

TSVETKOV, T. \& TAKEVA, T., 1988, Changes in interstitial gland in the ovary of the bat Rinolaphus eurale Blas: arousal from hibernation. Cryobiology., 25: 502-507. 